\title{
Deciphering the role of fluctuation dependent intercellular communication in neural stem cell development
}

\author{
Amitava Giri ${ }^{1}$, Dola Sengupta ${ }^{2}$ and Sandip $\operatorname{Kar}^{1}{ }^{*}$ \\ ${ }^{1}$ Department of Chemistry, IIT Bombay, Powai, Mumbai - 400076, India \\ ${ }^{2}$ Department of Chemistry, Techno India University, Salt Lake, Kolkata-700091, India
}

Corresponding author

*E-mail: sandipkar@iitb.ac.in 
Table S1: Equations governing the dynamics of the system

\begin{tabular}{|c|c|c|}
\hline$\frac{d H 1 p t_{i}}{d t}$ & $\begin{array}{c}=k_{\text {synp }} \times H e s 1 m_{i}-\frac{k_{d y n} \times\left(H 1 p t_{i}-y_{i}\right) \times H e s 6 p_{i}}{k_{m m}+\left(H 1 p t_{i}-y_{i}\right)} \\
-k_{d H e s 1} \times\left(H 1 p t_{i}-y_{i}\right)\end{array}$ & 1 \\
\hline$\frac{d H e s 1 m_{i}}{d t}$ & $\begin{array}{c}=J_{0}+\frac{k_{s y n}}{k_{m c}+k_{h e f f}\left[P_{4 c i}+\frac{P_{3 c i}}{a}+\frac{P_{2 c i}}{a^{2}}+\frac{P_{1 c i}}{a^{3}}\right]+k_{h n e f f} \times N g n 2 p_{i}} \\
+k_{a c t} \times N I C D_{i}-k_{d x n} \times H e s 1 m_{i}\end{array}$ & 2 \\
\hline$\frac{d H 1 p 2_{i}}{d t}$ & $\begin{array}{c}=k_{c} \times\left(H 1 p t_{i}-y_{i}\right)^{2}-k_{d} \times H 1 p 2_{i}-k_{e} \times H 1 p 2_{i} \times\left(G T L E t-x_{i}\right) \\
+k_{f} \times G P_{2 i} \times H e s 6 p_{i}\end{array}$ & 3 \\
\hline$\frac{d G P 2_{i}}{d t}$ & $\begin{array}{c}=k_{e} \times H 1 p 2_{i} \times\left(G T L E t-x_{i}\right)-k_{f} \times G P_{2 i} \times H e s 6 p_{i}-k_{s} \times G P_{2 i} \\
+k_{r} \times P_{1 c i}+k_{x 3} \times G P_{2 i}^{1}-k_{y 3} \times G P_{2 i} \times M A P K\end{array}$ & 4 \\
\hline$\frac{d P_{1 c i}}{d t}$ & $\begin{aligned}=k_{s} \times G P_{2 i}-k_{r} \times P_{1 c i}-k_{x} \times P_{1 c i}+k_{y} \times P_{2 c i} \\
-k_{x 1} \times P_{1 c i} \times M A P K+k_{y 1} \times G P_{2 i}^{2}\end{aligned}$ & 5 \\
\hline$\frac{d P_{2 c i}}{d t}$ & $\begin{array}{r}=k_{x} \times P_{1 c i}-k_{y} \times P_{2 c i}-k_{x} \times P_{2 c i}+k_{y} \times P_{3 c i} \\
-k_{x 1} \times P_{2 c i} \times M A P K+k_{y 1} \times G P_{2 i}^{3}\end{array}$ & 6 \\
\hline$\frac{d P_{3 c i}}{d t}$ & $=\boldsymbol{k}_{x} \times \boldsymbol{P}_{2 c i}-\boldsymbol{k}_{y} \times \boldsymbol{P}_{3 c i}-\boldsymbol{k}_{x} \times \boldsymbol{P}_{3 c i}+\boldsymbol{k}_{y} \times \boldsymbol{P}_{4 c i}$ & 7 \\
\hline$\frac{d P_{4 c i}}{d t}$ & $=\boldsymbol{k}_{x} \times P_{3 c i}-\boldsymbol{k}_{y} \times P_{4 c i}$ & 8 \\
\hline$\frac{d G P_{2 i}^{3}}{d t}$ & $=k_{x 1} \times P_{2 c i} \times M A P K-k_{y 1} \times G P_{2 i}^{3}-k_{x 2} \times G P_{2 i}^{3}+k_{y 2} \times G P_{2 i}^{2}$ & 9 \\
\hline$\frac{d G P_{2 i}^{2}}{d t}$ & $\begin{array}{c}=k_{x 1} \times P_{1 c i} \times M A P K-k_{y 1} \times G P_{2 i}^{2}-k_{x 2} \times G P_{2 i}^{2}+k_{y 2} \times G P_{2 i}^{1} \\
+k_{x 2} \times G P_{2 i}^{3}-k_{y 2} \times G P_{2 i}^{2}\end{array}$ & 10 \\
\hline$\frac{d G P_{2 i}^{1}}{d t}$ & $=k_{y 3} \times G P_{2 i} \times M A P K-k_{y 2} \times G P_{2 i}^{1}-k_{x 3} \times G P_{2 i}^{1}+k_{x 2} \times G P_{2 i}^{2}$ & 11 \\
\hline$\frac{d H e s 6 m_{i}}{d t}$ & $=k_{s 6 m}+k_{a c h} \times N g n 2 p_{i}-k_{d 6 m} \times H e s 6 m_{i}$ & 12 \\
\hline$\frac{d H e s 6 m_{i}}{d t}$ & $=k_{s 6 p} \times H e s 6 m_{i}-k_{d 6 p} \times H e s 6 p_{i}$ & 13 \\
\hline
\end{tabular}




$$
\begin{aligned}
& \frac{d N g n 2 m_{i}}{d t}=J_{n}+\frac{k_{n}}{k_{m c 2}+k_{n e f f}\left[P_{4 c i}+\frac{P_{3 c i}}{b}+\frac{P_{2 c i}}{b^{2}}+\frac{P_{1 c i}}{b^{3}}\right]}-k_{d n m} \times N g n 2 m_{i} \\
& \frac{d N g n 2 p_{i}}{d t}=k_{s y n 2 p} \times N g n 2 m_{i}-k_{d n p} \times N g n 2 p_{i} \\
& \frac{d D l l 1 m_{i}}{d t}=k_{s d l m}+\frac{k_{s y d}}{k_{m m d}+k_{\text {deff }}\left[P_{4 c i}+\frac{P_{3 c i}}{d}+\frac{P_{2 c i}}{d^{2}}+\frac{P_{1 c i}}{d^{3}}\right]} \\
& +k_{\text {actn }} \times N g n 2 p_{i}-k_{d d l m} \times D l l 1 m_{i} \\
& \frac{d D l l 1 p_{i}}{d t}=\underset{i \neq j}{k_{s d l p} \times D l l 1 m_{i}-k_{d d l p} \times D l l 1 p_{i}-k_{N I C D} \times D l l 1 p_{i} \times N_{o t c h p}, \quad 17} \\
& \frac{d N o t c h m_{i}}{d t}=k_{s n o}+k_{g f} \times G F+k_{s e r} \times S e r-k_{d n o m} \times N o t c h m_{i} \\
& \begin{array}{c}
\frac{d N o t c h p_{i}}{d t}=k_{\text {syno }} \times N_{\text {otchm }} \\
-k_{d n o p} \\
i \neq j
\end{array} \\
& \underline{d N I C D_{i}}=k_{N I C D} \times D l l 1 p_{j} \times N o t c h p_{i}-k_{d N I C D} \times N I C D_{i}+J_{N I C D}, \quad i \neq j \quad 20 \\
& x_{i} \quad=G P_{2 i}+P_{1 c i}+P_{2 c i}+P_{3 c i}+P_{4 c i}+G P_{2 i}^{3}+G P_{2 i}^{2}+G P_{2 i}^{1} \\
& y_{i} \quad=2 \times\left(x_{i}+H 1 p 2_{i}\right)
\end{aligned}
$$

\begin{tabular}{|c|c|}
\hline $\begin{array}{l}\text { Abbreviated } \\
\text { names }\end{array}$ & Description \\
\hline$H 1 m_{i}$ & Hes 1 mRNA of $i^{\text {th }}$ cell \\
\hline$H 1 p 2_{i}$ & Dimer of Hes1 protein of $i^{\text {th }}$ cell \\
\hline$H 1 p t_{i}$ & Total Hes 1 protein of $i^{\text {th }}$ cell \\
\hline$G P_{2 i}$ & $H 1 p 2_{i}: \mathrm{Gro} / \mathrm{TLE}$ \\
\hline$P_{1 c i}$ & Phosphorylated form of $G P_{2 i}$ \\
\hline$P_{2 c i}$ & Doubly phosphorylated form of $G P_{2 i}$ \\
\hline$P_{3 c i}$ & Triply phosphorylated form of $G P_{2 i}$ \\
\hline
\end{tabular}

Table S2: Abbreviated names and description of species involved in the model 


\begin{tabular}{|c|c|}
\hline $\boldsymbol{P}_{4 c i}$ & Four times phosphorylated form of $G P_{2 i}$ \\
\hline$G P_{2 i}^{3}$ & One time negatively phosphorylated inactive form of $G P_{2 i}$ \\
\hline$G P_{2 i}^{2}$ & One time negatively phosphorylated inactive form of $P_{1 c i}$ \\
\hline$G P_{2 i}^{1}$ & One time negatively phosphorylated inactive form of $P_{2 c i}$ \\
\hline $\operatorname{Dll1m}_{i}$ & Dll1 mRNA of $i^{\text {th }}$ cell \\
\hline $\operatorname{Dll1}_{i}$ & Dll1 protein of $\mathrm{i}^{\text {th }}$ cell \\
\hline $\operatorname{Ngnm}_{i}$ & Ngn mRNA of $i^{\text {th }}$ cell \\
\hline$N g n p_{i}$ & Ngn protein of $i^{\text {th }}$ cell \\
\hline$N I C D_{i}$ & Notch inter cellular domain protein of $\mathrm{i}^{\text {th }}$ cell \\
\hline GTLEt & Total Gro/TLE protein \\
\hline Notchm $_{i}$ & Notch mRNA of $i^{\text {th }}$ cell \\
\hline $\operatorname{Notchp}_{i}$ & Notch protein of $i^{\text {th }}$ cell \\
\hline Hes6mi & Hes 6 protein of $i^{\text {th }}$ cell \\
\hline Hes6p & Hes 6 protein of $i^{\text {th }}$ cell \\
\hline
\end{tabular}

Table S3: Description and values of parameters

\begin{tabular}{|c|c|c|}
\hline Symbol & Description & Value \\
\hline $\boldsymbol{k}_{\text {syn }}$ & Transcription rate of Hes1 mRNA & 1800 molecules $\min ^{-1}$ \\
\hline $\boldsymbol{k}_{\boldsymbol{m} c}$ & $\begin{array}{l}\text { Michaelis constant related to transcription of Hes } 1 \\
\text { mRNA }\end{array}$ & 15 \\
\hline $\boldsymbol{k}_{n}$ & Transcription rate of Ngn mRNA & $\begin{array}{l}\text { Control bifurcation } \\
\text { parameter } \\
\text { molecules } \text { min }^{-1}\end{array}$ \\
\hline $\boldsymbol{k}_{\boldsymbol{m} c 2}$ & $\begin{array}{l}\text { Michaelis constant related to transcription of Ngn } \\
\text { mRNA }\end{array}$ & 18 \\
\hline $\boldsymbol{k}_{\text {syd }}$ & Transcription rate of D111 mRNA & 760.5 molecules min $^{-}$ \\
\hline $\boldsymbol{k}_{\boldsymbol{m} m \boldsymbol{d}}$ & $\begin{array}{l}\text { Michaelis constant related to transcription of D1l1 } \\
\text { mRNA }\end{array}$ & 15 \\
\hline
\end{tabular}




\begin{tabular}{|c|c|c|}
\hline $\boldsymbol{k}_{\text {sno }}$ & Transcription rate of Notch mRNA & 1.386 molecule $\min ^{-1}$ \\
\hline$k_{s 6 m}$ & Transcription rate of Hes6 mRNA & $\begin{array}{c}0.14535 \text { molecule } \\
\text { min }^{-1}\end{array}$ \\
\hline$J_{0}$ & Basal synthesis of Hes1 mRNA & 4.5 molecules $\min ^{-1}$ \\
\hline$J_{n}$ & Basal synthesis of Ngn mRNA & 7.5 molecules $\mathrm{min}^{-1}$ \\
\hline $\boldsymbol{k}_{\text {sdlm }}$ & Basal synthesis of Dll1 mRNA & 1.5 molecule $\min ^{-1}$ \\
\hline $\boldsymbol{k}_{\text {synp }}$ & Translation rate of Hes 1 protein & $5.8 \mathrm{~min}^{-1}$ \\
\hline$k_{\text {syn } 2 p}$ & Translation rate of Ngn protein & $7.5 \mathrm{~min}^{-1}$ \\
\hline$k_{\text {sydlp }}$ & Translation rate of Dll1 protein & $0.5 \min ^{-1}$ \\
\hline$k_{\text {syno }}$ & Translation rate of Notch protein & $0.5 \min ^{-1}$ \\
\hline$k_{s 6 p}$ & Translation rate of Hes 6 protein & $0.1 \min ^{-1}$ \\
\hline $\boldsymbol{k}_{d x n}$ & Degradation constant of Hes1 mRNA & $0.0288 \mathrm{~min}^{-1}$ \\
\hline $\boldsymbol{k}_{\text {dhes } 1}$ & Degradation constant of Hes1 protein & $0.031 \mathrm{~min}^{-1}$ \\
\hline $\boldsymbol{k}_{\text {dyn }}$ & $\begin{array}{l}\text { Rate constant of Hes } 6 \text { mediated Hes } 1 \text { protein } \\
\text { degradation }\end{array}$ & $1.9 \mathrm{~min}^{-1}$ \\
\hline $\boldsymbol{k}_{\boldsymbol{m} m}$ & $\begin{array}{l}\text { Michaelis constant corresponding to Hes } 6 \text { protein } \\
\text { mediated Hes } 1 \text { protein degradation }\end{array}$ & 0.015 molecule \\
\hline $\boldsymbol{k}_{d n m}$ & Degradation constant of Ngn mRNA & $0.0288 \mathrm{~min}^{-1}$ \\
\hline $\boldsymbol{k}_{d n p}$ & Degradation constant of Ngn protein & $0.031 \mathrm{~min}^{-1}$ \\
\hline $\boldsymbol{k}_{d d l m}$ & Degradation constant of D111 mRNA & $0 . .0288 \mathrm{~min}^{-1}$ \\
\hline $\boldsymbol{k}_{\text {ddlp }}$ & Degradation constant of Dll1 protein & $0.031 \mathrm{~min}^{-1}$ \\
\hline $\boldsymbol{k}_{\text {dnom }}$ & Degradation constant of Notch mRNA & $0.006 \mathrm{~min}^{-1}$ \\
\hline $\boldsymbol{k}_{\text {dnop }}$ & Degradation constant of Notch protein & $0.017 \mathrm{~min}^{-1}$ \\
\hline$k_{d s 6 m}$ & Degradation constant of Hes6 mRNA & $0.028 \mathrm{~min}^{-1}$ \\
\hline$k_{d s 6 p}$ & Degradation constant of Hes6 protein & $0.031 \mathrm{~min}^{-1}$ \\
\hline $\boldsymbol{k}_{d N I C D}$ & Degradation constant of NICD & $0.03 \mathrm{~min}^{-1}$ \\
\hline $\boldsymbol{k}_{c}$ & Hes1 protein dimerization constant & 1.0 molecule $^{-1} \mathrm{~min}^{-1}$ \\
\hline
\end{tabular}




\begin{tabular}{|c|c|c|}
\hline $\boldsymbol{k}_{\boldsymbol{d}}$ & $\mathrm{H} 1 \mathrm{p}_{2}$ dissociation constant & $1400 \mathrm{~min}^{-1}$ \\
\hline $\boldsymbol{k}_{e}$ & $\begin{array}{l}\text { Gro/TLE protein association constant with } \mathrm{H}_{1} p_{2} \\
\text { molecules }\end{array}$ & $\begin{array}{l}0.833 \text { molecule }^{-1} \\
\text { min }^{-1}\end{array}$ \\
\hline $\boldsymbol{k}_{f}$ & GP2 dissociation constant & 1.67 molecule $_{1}^{-1}$ min $^{-}$ \\
\hline $\boldsymbol{k}_{\boldsymbol{s}}$ & Phosphorylation rate of GP2 & $2.5 \mathrm{~min}^{-1}$ \\
\hline $\boldsymbol{k}_{x}$ & Phosphorylation rate of $\mathrm{P} 1 \mathrm{c}, \mathrm{P} 2 \mathrm{c}, \mathrm{P} 3 \mathrm{c}$ & $0.56 \mathrm{~min}^{-1}$ \\
\hline $\boldsymbol{k}_{\boldsymbol{r}}$ & Dephosphorylation rate of $\mathrm{P} 1 \mathrm{c}$ & $0.5 \mathrm{~min}^{-1}$ \\
\hline $\boldsymbol{k}_{\boldsymbol{y}}$ & Dephosphorylation rate of $\mathrm{P} 2 \mathrm{c}, \mathrm{P} 3 \mathrm{c}, \mathrm{P} 4 \mathrm{c}$ & $0.54 \min ^{-1}$ \\
\hline $\boldsymbol{k}_{x 1}$ & $\begin{array}{l}\text { MAPK }(\mathrm{X}) \text { mediated phosphorylation rate of P1c } \\
\text { and P2c }\end{array}$ & $10^{-5}$ molecule $^{-1} \min ^{-1}$ \\
\hline$k_{y 1}$ & $\begin{array}{l}\text { Dephosphorylation rate of } 3 \mathrm{GP} 2 \text { and } 2 \mathrm{GP} 2 \text { to } \mathrm{P} 2 \mathrm{c} \\
\text { and } \mathrm{P} 1 \mathrm{c} \text { respectively }\end{array}$ & $0.01 \mathrm{~min}^{-1}$ \\
\hline $\boldsymbol{k}_{x 2}$ & $\begin{array}{l}\text { Dephosphorylation rate of } 3 \mathrm{GP} 2 \text { to } 2 \mathrm{GP} 2 \text { and from } \\
2 \mathrm{GP} 2 \text { to } 1 \mathrm{GP} 2\end{array}$ & $0.01 \mathrm{~min}^{-1}$ \\
\hline $\boldsymbol{k}_{y 2}$ & $\begin{array}{l}\text { Phosphorylation rate of } 2 \mathrm{GP} 2 \text { to } 3 \mathrm{GP} 2 \text { and from } \\
1 \mathrm{GP} 2 \text { to } 2 \mathrm{GP} 2\end{array}$ & $0.02 \mathrm{~min}^{-1}$ \\
\hline $\boldsymbol{k}_{x 3}$ & Dephosphorylation rate of $1 \mathrm{GP} 2$ to GP2 & $0.01 \mathrm{~min}^{-1}$ \\
\hline $\boldsymbol{k}_{y 3}$ & $\begin{array}{l}\text { MAPK (X) mediated phosphorylation rate of GP2 to } \\
1 \mathrm{GP} 2\end{array}$ & 0.0001 \\
\hline $\boldsymbol{X}$ & Total MAPK (X) molecules & 100 molecule \\
\hline $\boldsymbol{k}_{\text {ach }}$ & $\begin{array}{l}\text { Rate constant related to transcriptional activation of } \\
\text { Hes } 6 \text { mRNA by Ngn protein }\end{array}$ & $0.005 \mathrm{~min}^{-1}$ \\
\hline $\boldsymbol{k}_{\text {actn }}$ & $\begin{array}{l}\text { Rate constant related to transcriptional activation of } \\
\text { D111 mRNA by Ngn protein }\end{array}$ & $0.002 \mathrm{~min}^{-1}$ \\
\hline $\boldsymbol{k}_{N I C D}$ & $\begin{array}{l}\text { Rate of formation of NICD upon binding of Notch } \\
\text { and Dll1 }\end{array}$ & $\begin{array}{l}\quad 6.7 \times 10^{-5} \\
\text { molecule }{ }^{-1} \min ^{-1}\end{array}$ \\
\hline $\boldsymbol{k}_{\text {act }}$ & $\begin{array}{l}\text { Rate constant related to transcriptional activation of } \\
\text { Hes } 1 \text { mRNA by NICD protein }\end{array}$ & $0.0015 \mathrm{~min}^{-1}$ \\
\hline$k_{\text {heff }}$ & $\begin{array}{l}\text { General repression rate of Hes } 1 \text { by phosphorylated } \\
\text { forms of Hes } 1 \text { proteins }\end{array}$ & 0.8 molecule $^{-1}$ \\
\hline
\end{tabular}




\begin{tabular}{|c|c|c|}
\hline$k_{n e f f}$ & $\begin{array}{l}\text { General repression rate of Ngn by phosphorylated } \\
\text { forms of Hes } 1 \text { proteins }\end{array}$ & 0.3 molecule $^{-1}$ \\
\hline$k_{\text {deff }}$ & $\begin{array}{l}\text { General repression rate of D1l1 by phosphorylated } \\
\text { forms of Hes } 1 \text { proteins }\end{array}$ & 1.5 molecule $^{-1}$ \\
\hline$k_{\text {hneff }}$ & General repression rate of Hes 1 by Ngn proteins & 0.0003 molecule $^{-1}$ \\
\hline$a$ & $\begin{array}{l}\text { A dimensionless constant to modulate the effect of } \\
\text { Pic mediated transcriptional inhibition to Hes } 1 \\
\text { (where I varies from } 1 \text { to } 4 \text { ) }\end{array}$ & 5 \\
\hline $\boldsymbol{b}$ & $\begin{array}{l}\text { A dimensionless constant to modulate the effect of } \\
\text { Pic mediated transcriptional inhibition to Ngn (where } \\
\text { i varies from } 1 \text { to } 4 \text { ) }\end{array}$ & 15 \\
\hline$d$ & $\begin{array}{l}\text { A dimensionless constant to modulate the effect of } \\
\text { Pic mediated transcriptional inhibition to D1l1 (where } \\
\text { i varies from } 1 \text { to } 4 \text { ) }\end{array}$ & 10 \\
\hline$k_{g f}$ & $\begin{array}{l}\text { Rate constant related to the effect of FGF on Notch } \\
\text { mRNA }\end{array}$ & $0.015 \mathrm{~min}^{-1}$ \\
\hline $\boldsymbol{k}_{\text {ser }}$ & $\begin{array}{l}\text { Rate constant related to the effect of serum on Notch } \\
\text { mRNA }\end{array}$ & $0.03 \mathrm{~min}^{-1}$ \\
\hline
\end{tabular}

Table S4: Mean and CV of transcription rates used in stochastic simulation
Parameter
Mean value
CV

\begin{tabular}{|c|c|c|}
\hline $\boldsymbol{k}_{\text {syn }}$ & 1800 molecule min $^{-1}$ & $15 \%$ \\
\hline $\boldsymbol{k}_{n}$ & 675 molecule min $^{-1}$ & $15 \%$ \\
\hline$k_{\text {syd }}$ & 760.5 molecule $\min ^{-1}$ & $15 \%$ \\
\hline $\boldsymbol{k}_{\text {sno }}$ & 1.386 molecule $\mathrm{min}^{-1}$ & $15 \%$ \\
\hline$k_{s 6 m}$ & 0.14535 molecule $\min ^{-1}$ & $15 \%$ \\
\hline
\end{tabular}




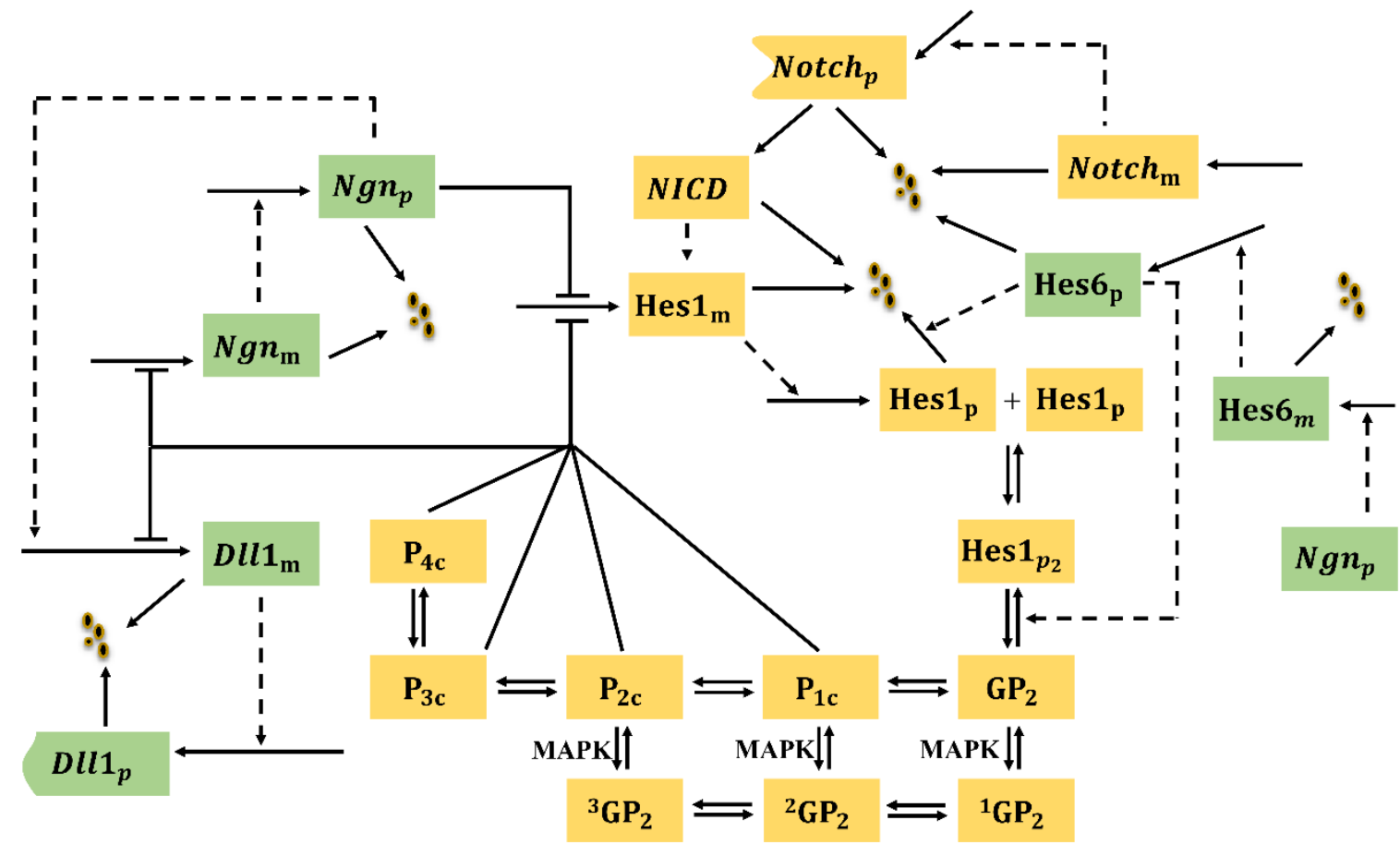

Figure S1: Complete regulatory network of Hes1 that governs the cell fate decision making events of neural stem cells.

(a)

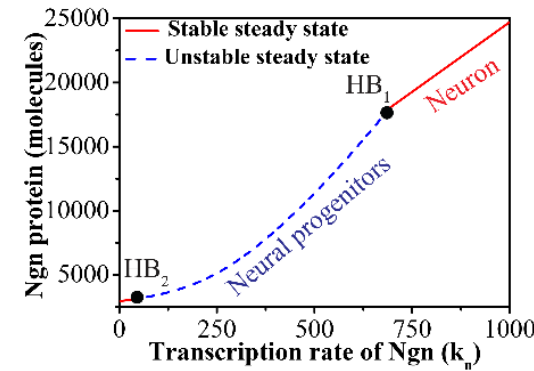

(b)

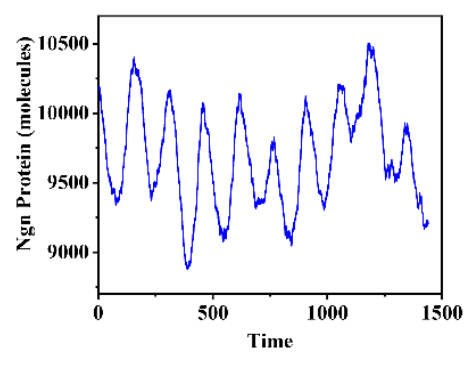

(c)

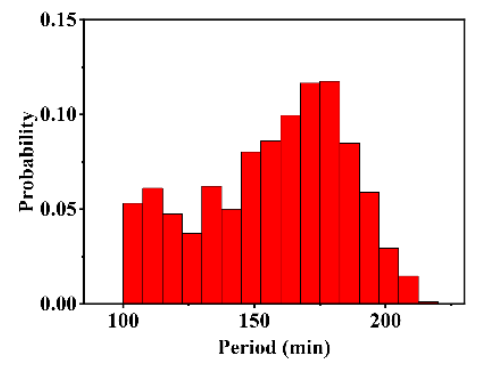

Figure S2: Dynamics of Ngn protein in neural progenitor cells. (a) Steady state dynamics of Ngn protein as a function of transcription rate of $\operatorname{Ngn}\left(\mathrm{k}_{\mathrm{n}}\right)$. (b) Oscillatory stochastic time profile of Ngn protein. Value of

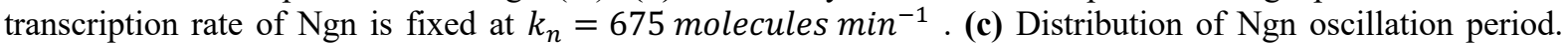
Average period of oscillation of Ngn is $157.08 \pm 27.55 \mathrm{~min}$. 


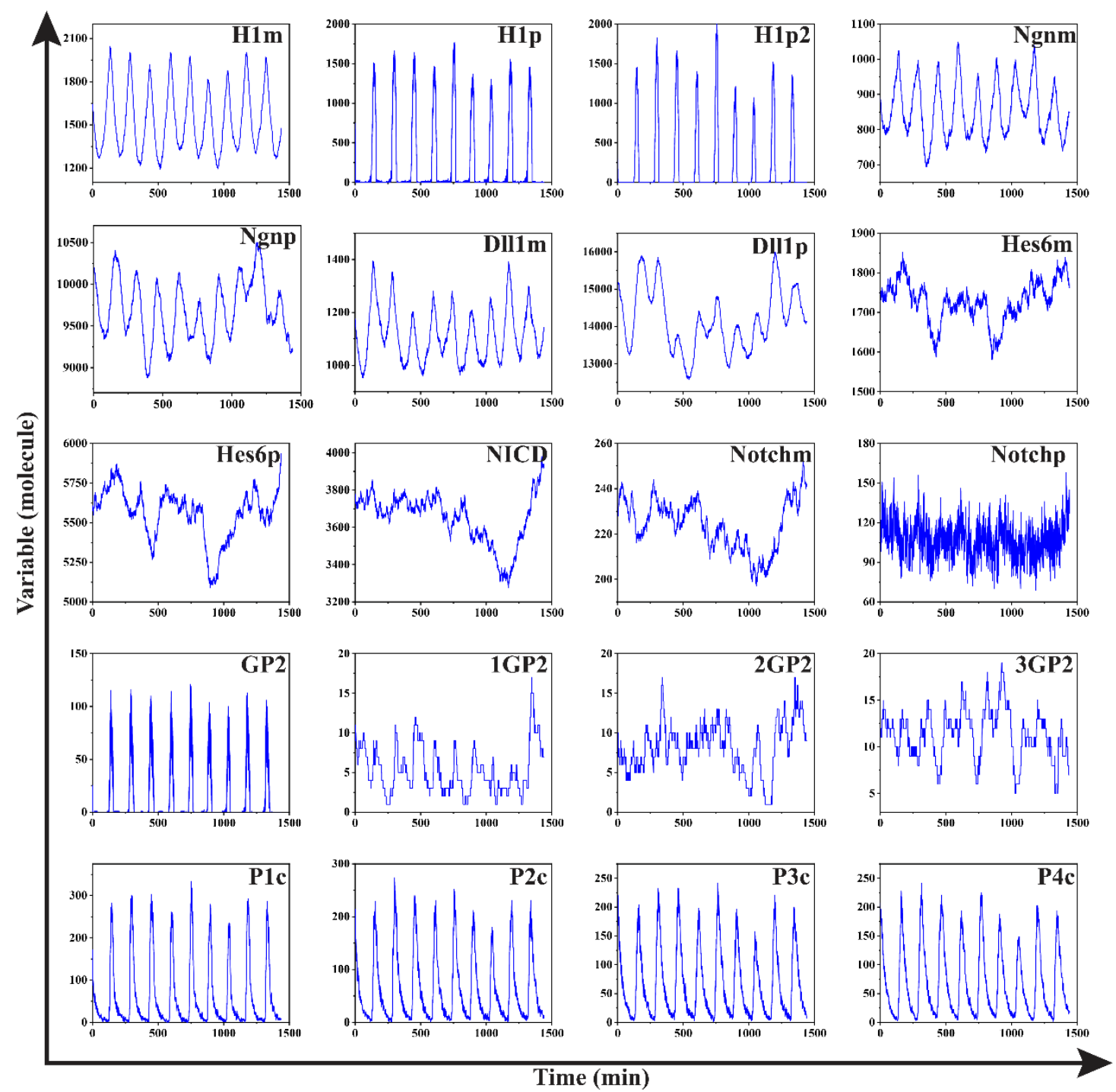

Figure S3: Stochastic time course trajectory of all the variables.

(a)

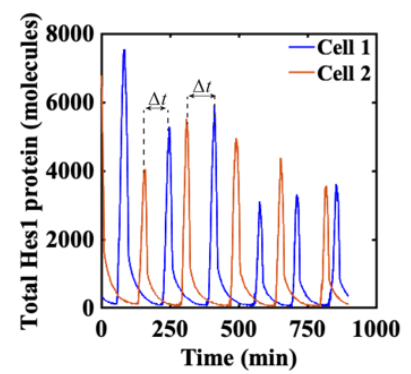

(b)

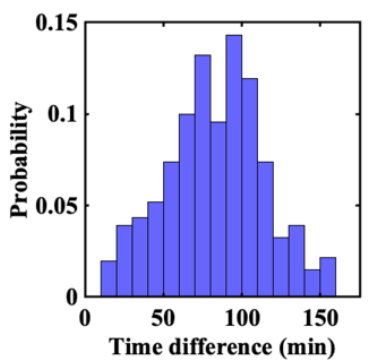

(c)

\begin{tabular}{|c|c|c|c|}
\hline $\begin{array}{c}\text { Cell cycle } \\
\text { variability }\end{array}$ & $\begin{array}{c}\text { Mean } \\
\text { (min) }\end{array}$ & $\begin{array}{c}\text { std } \\
\text { (min) }\end{array}$ & CV \\
\hline $\mathbf{5 \%}$ & 81.57 & 32.93 & $40.37 \%$ \\
\hline $\mathbf{1 0} \%$ & 76.49 & 30.29 & $39.60 \%$ \\
\hline $\mathbf{1 5 \%}$ & 81.93 & 33.64 & $41.05 \%$ \\
\hline
\end{tabular}

Figure S4: Results of stochastic simulation reconcile the out of phase oscillatory behavior of two neighboring NPCs. (a) Time course trajectory of two neighboring NPCs. $\Delta t$ is the time difference between the $i^{\text {th }}$ peak of cell 1 and cell 2. (b) Distribution of time difference $(\Delta t)$. Here we have considered the $5 \%$ cell cycle variability. (c) Effect of cell cycle variability on the time difference distribution. With increasing the cell cycle variability (one source of non-genetic heterogeneity) there is no significant change of coefficient of variation of time difference distribution. 


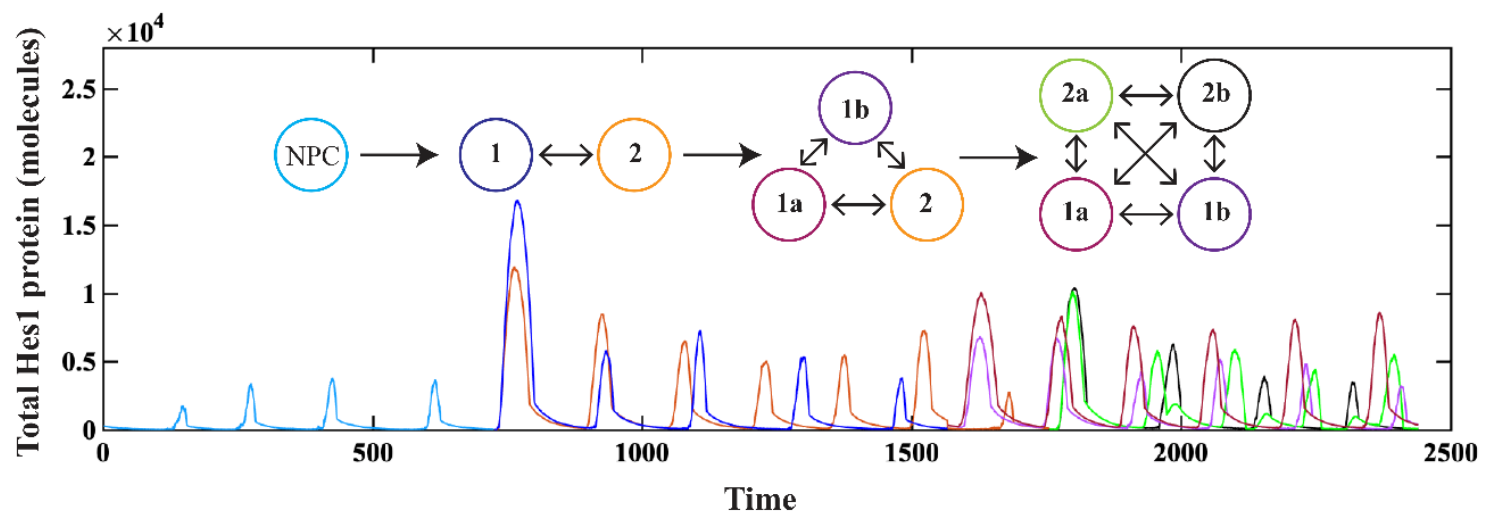

Figure S5: Time course trajectory of Hes1 protein in a series of cell division events. The neural progenitor cell is committing a symmetric cell division. In both the cells Hes1 is showing oscillatory behavior. Here both the progenitor cells (cell 1 and cell 2) are again committing symmetric cell divisions and in all the daughter cells, Hes 1 is oscillating. In this scenario, at the end of the simulation time there are four NPCs.

(a)

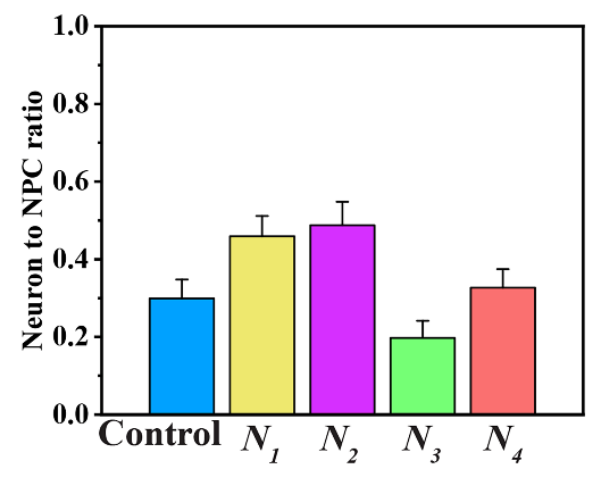

(b)

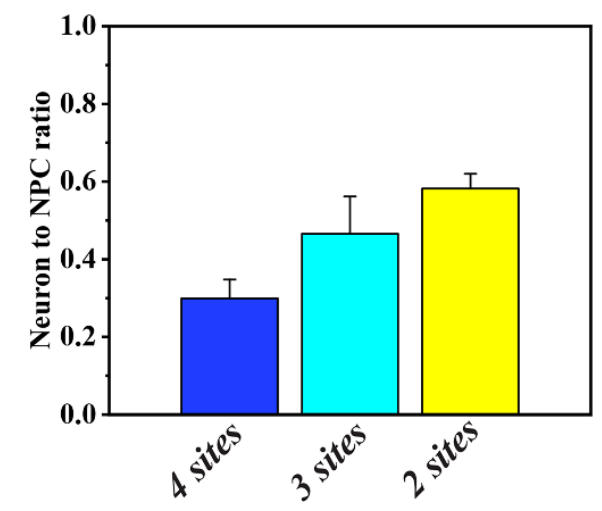

Figure S6: Probable ways to alter the neuron to NPC ratio. (a) Effect of different negative regulation in maintaining the neuron to NPC ratio for a synchronized population of neural progenitor cells (b) Deletion of phosphorylation sites increases the neuron to NPC ratio for a synchronized population of neural progenitor cells.

(a)

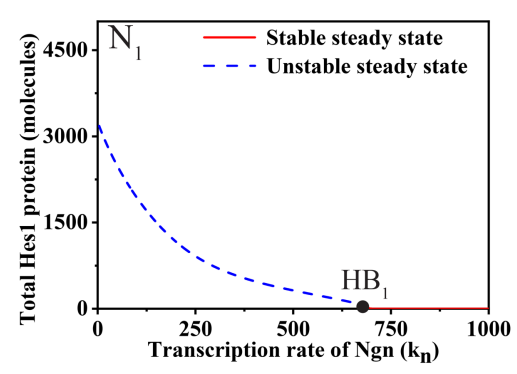

(d)

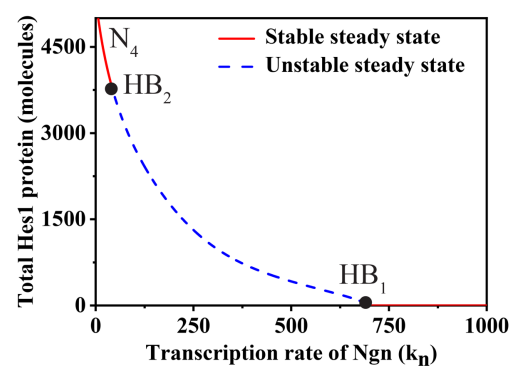

(b)

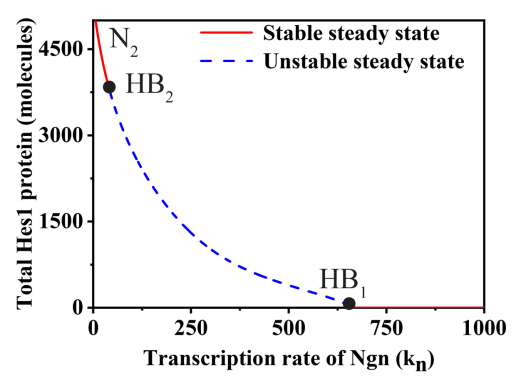

(e)

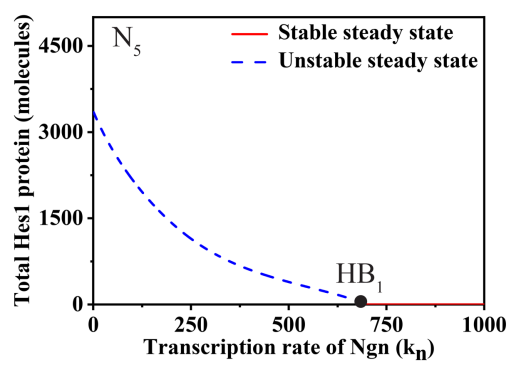

(c)

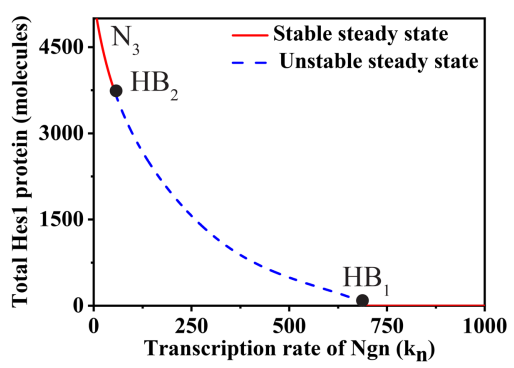

(f)

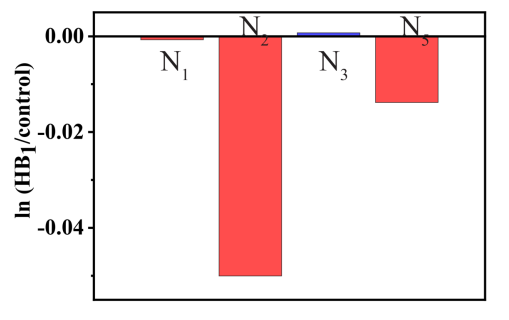

Figure S7: Deterministic bifurcation analysis predicts the way to alter neuron to NPC ratio. Parameters corresponding to the negative loops $\left(\mathrm{N}_{1}, \mathrm{~N}_{2}, \mathrm{~N}_{3}\right.$ and $\left.\mathrm{N}_{4}\right)$ are increased by $20 \%$. Bifurcation diagram of Hes1 
protein steady state with increased parameter value (a) $\mathrm{N}_{1}$ (b) $\mathrm{N}_{2}$ (c) $\mathrm{N}_{3}$ and (d) $\mathrm{N}_{4}$. (e) In this scenario we have increased the basal synthesis rate of Hes6 by 10 times. (f) Sensitivity of the $\mathrm{HB}_{1}$ point with different negative loop. Red bar denotes the shift of $\mathrm{HB}_{1}$ point towards lower value compared to the control. Blue colored bar represents the shift of $\mathrm{HB}_{1}$ point towards higher value compared to the control.

\section{(a)}

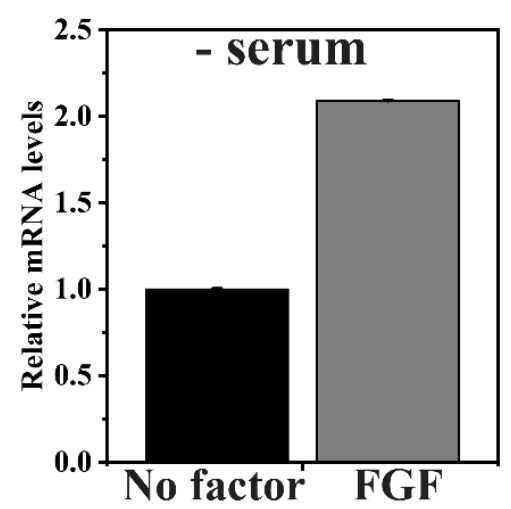

(b)

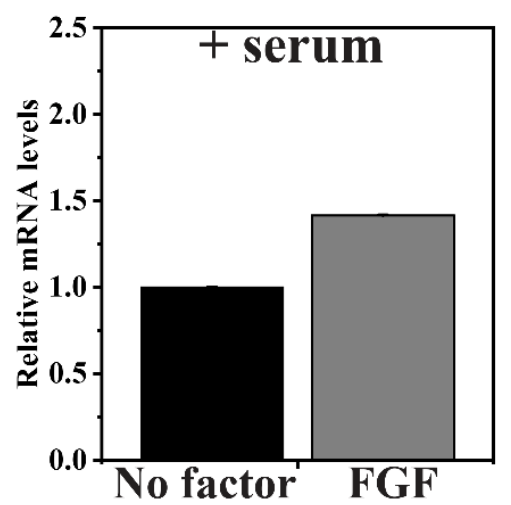

Figure S8: Alteration of neuron to NPC ratio by FGF happens through the induction of Notch mRNA. Effect of FGF on Notch mRNA level (a) in absence of serum and (b) in presence of serum. 